\title{
A mutant screening method by critical annealing temperature-PCR for site-directed mutagenesis
}

\author{
Ying Liu ${ }^{1,2}$, Ting $\mathrm{Wu}^{2,4}$, Jian Song ${ }^{2,3}$, Xuelian Chen ${ }^{1,2}$, Yu Zhang ${ }^{1,2}$ and Yu Wan ${ }^{1,2^{*}}$
}

\begin{abstract}
Background: Distinguishing desired mutants from parental templates and undesired mutants is a problem not well solved in Quikchange ${ }^{\mathrm{TM}}$ mutagenesis. Although Dpn I digestion can eliminate methylated parental (WT) DNA, the efficiency is not satisfying due to the existence of hemi-methylated DNA in the PCR products, which is resistant to Dpn I. The present study designed a novel critical annealing temperature $\left(T_{c}\right)-P C R$ to replace Dpn I digestion for more perfect mutant distinguishing, in which part-overlapping primers containing mutation(s) were used to reduce initial concentration of template DNA in mutagenic PCR. A $T_{c}-P C R$ with the same mutagenic primers was performed without $D p n$ I digestion. The $T_{c}$ for each pair of the primers was identified by gradient PCR. The relationship between PCR-identified $T_{c}$ and $T_{m}$ of the primers was analyzed and modeled with correlation and regression.

Results: Gradient PCR identified a $T_{c}$ for each of 14 tested mutagenic primers, which could discriminate mismatched parental molecules and undesired mutants from desired mutants. The PCR-identified $T_{c}$ was correlated to the primer's $T_{m}(r=0.804, P<0.0001)$. Thus, in practical applications, the $T_{c}$ can be easily calculated with a regression equation, $T_{c}=48.81+0.253^{*} T_{\mathrm{m}}$.

Conclusions: The new protocol introduced a novel $T_{c}-P C R$ method for mutant screening which can more efficiently and accurately select against parental molecules and undesired mutations in mutagenic sequence segments.
\end{abstract}

Keywords: Mutant screening, Dpn I digestion, Critical annealing temperature-PCR, Site-directed mutagenesis

\section{Background}

PCR-based one-step site-directed mutagenesis (SDM) is an efficient and rapid method to generate gene mutation(s) for study of protein structure-function relationship, identification of gene expression and modification of vector [1-3]. Since established by Agilent Technologies according to Papworth et al. [4] and Nelson et al. [5], the QuikChange ${ }^{\text {TM }}$ Site-Directed Mutagenesis System has been modified by a number of authors to make its procedure more simple and operable [6-11]. The principle of this technique is taking the double-stranded DNA of a target gene as the template and using a pair of overlapping oligonucleotide primers containing desired mutation to produce mutants by PCR. There are two concerns about this technology. Firstly, the

\footnotetext{
* Correspondence: wanyu@whu.edu.cn

'Department of Physiology, School of Basic Medical Sciences, Wuhan University, Hubei 430071, People's Republic of China

${ }^{2}$ Center for Medical Research, Wuhan University, Hubei 430071, People's Republic of China

Full list of author information is available at the end of the article
}

number of cycles during PCR should be reduced to prevent undesired mutations; the resultant lower product yield can be offset by increasing the starting template concentration. Secondly, the parental (WT) DNA existing in final PCR products must be removed. For this, a mutant selection by digestion of $D p n$ I endonuclease is usually performed after PCR. However, although Dpn I (target sequence 5-GA ${ }^{\mathrm{m}} \mathrm{TC}$ ) can quickly digest fully methylated DNA (parental strands from bacterial strains), its reaction with hemi-methylated DNA (parental strand combined with PCR-generated strand) is 60-fold slower. Thus the final PCR mixture inevitably contains small amount of parental molecules. In addition, Dpn I digestion cannot select against undesired mutations. Here, the present study designed a novel critical annealing temperature $\left(T_{\mathrm{c}}\right)$-PCR method for more perfect mutant distinguishing, which can be used without $D p n$ I digestion. The $T_{\mathrm{c}}$ is derived from a regression equation, which can select against parental molecules up to a rate of $100 \%$ and undesired mutations located in mutagenic sequence segments.

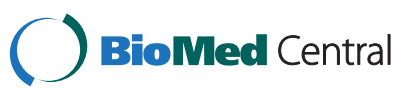




\section{Methods}

\section{Plasmid template}

The plasmids used as templates for PCR were constructed using pET20b (+) (69739-3; Novagen, Germany) and pcDNA3.1(+) (V790-20, Invitrogen). The cDNA of different genes with different length, including human growth hormone (hGH) without signal peptide (NM_000515.3; $573 \mathrm{bp}$ ), hGH 2 variant isoform 3 precursor (hGH2V3, NM_022558.3; 738 bp), hGH receptor (hGHR; NM_00 0163.4, $1920 \mathrm{bp}$ ), porcine $\mathrm{GH}$ binding protein (pGHBP, NM_214254.2, 570 bp) or hGH binding protein (hGHBP, NM_000163.4, 714 bp), was inserted into either pET20b (+) between Nde I and Hind III, or pcDNA3.1 (+) between Pst I and Eco RI. The plasmids were propagated in E. coli DH5alpha cells (Agilent Technologies, CA) and isolated using Qiagen miniprep kits (Qiagen, Germany).

\section{Primers and site-directed mutagenesis}

The primers for mutagenesis by PCR were designed basically according to the manufacturer (QuikChange ${ }^{\mathrm{TM}}$ Mutagenesis kit; Agilent Technologies, CA) but a modification was made according to Braman, et al. [4] and Liu, et al. [6] to reduce initial concentration of template DNA. Briefly, each pair of primers contained a non-overlapping sequence at the $3^{\prime}$-terminus and a primer-primer complementary (overlapping) sequence at the $5^{\prime}$-terminus. The non-overlapping sequence was significantly larger than the overlapping to make the melting temperature of the former higher than that of the latter. The designed primers listed in Table 1 were used for mutagenesis of the target residues D112G, D112K, I4V, L45D, E56D, R64D, R64M, N109Y and D116F in hGH molecule. All mutation sites were located in the complementary region, 3-7 bases

Table 1 The primers for site-directed mutagenesis

\begin{tabular}{|c|c|c|c|c|}
\hline Primer & Sequence & Length & Mismatches & $T_{\mathrm{m}}$ \\
\hline $\mathrm{D} 112 \mathrm{G}(\mathrm{F})$ & CTATGgCCTCCTAAAGGACCTAGAGGAAG & 29 & 1 & 76.0 \\
\hline $\mathrm{D} 112 \mathrm{G}(\mathrm{R})$ & GGAGGcCATAGACGTTGCTGTCAGAG & 26 & 1 & 75.3 \\
\hline $\mathrm{D} 112 \mathrm{~K}(\mathrm{~F})$ & CTATaAaCTCCTAAAGGACCTAGAGGAAG & 29 & 2 & 68.3 \\
\hline $\mathrm{D} 112 \mathrm{~K}(\mathrm{R})$ & GGAGtTtATAGACGTTGCTGTCAGAG & 26 & 2 & 66.8 \\
\hline $14 \mathrm{~V}(\mathrm{~F})$ & CAACCgTTCCCTTATCCAGGCTTITTG & 27 & 1 & 72.5 \\
\hline $14 V(R)$ & GAACGGTTGGGAACATATGTATATCTCCTTCT & 32 & 1 & 73.9 \\
\hline L45D(F) & CATTCgatCAGAACCCCCAGACCTCCCTCTGTTTCT & 36 & 3 & 76.1 \\
\hline $\mathrm{L} 45 \mathrm{D}(\mathrm{R})$ & GGTTCTGatcGAATGAATACTTCTGTTCCTITGGGAT & 37 & 3 & 71.8 \\
\hline $\mathrm{E} 56 \mathrm{D}(\mathrm{F})$ & TCAGACTCTATTCCGACACCCTCCAAC & 27 & 1 & 74.1 \\
\hline$E 56 D(R)$ & GAATAGAgTCTGAGAAACAGAGGGAGGTCTG & 31 & 1 & 76.3 \\
\hline $\mathrm{R} 64 \mathrm{D}(\mathrm{F})$ & CTCCAACgacGAGGAAACACAACAG & 25 & 3 & 63.8 \\
\hline $\mathrm{R} 64 \mathrm{D}(\mathrm{R})$ & CCTCgtcGTTGGAGGGTGTCGGAATAG & 27 & 3 & 69.7 \\
\hline N109Y(F) & CAGCtAtGTCTATGACCTCCTAAAGGACCTAGAGGAAG & 38 & 2 & 77.9 \\
\hline N109Y(R) & GACaTaGCTGTCAGAGGCGCCGTACACCAG & 30 & 2 & 76.9 \\
\hline $\mathrm{D} 116 \mathrm{~F}(\mathrm{~F})$ & AAAGttCCTAGAGGAAGGCATCCAAACGCTGAT & 33 & 2 & 73.6 \\
\hline $\mathrm{D} 116 \mathrm{~F}(\mathrm{R})$ & CTCTAGGaaCTTTAGGAGGTCATAGACGTTGCTGTCAG & 38 & 2 & 77.9 \\
\hline $\mathrm{R} 64 \mathrm{M}(\mathrm{F})$ & TCCAACAtGGAGGAAACACAACAG & 24 & 1 & 68.0 \\
\hline $\mathrm{R} 64 \mathrm{M}(\mathrm{R})$ & TCCaTGTTGGAGGGTGTCGGAATAG & 25 & 1 & 71.8 \\
\hline hGH2V3-P233S(F) & TGGtCgTGGAAGgTGCTACTCCAGTGCCCACCAGCC & 36 & 3 & 80.6 \\
\hline hGH2V3-P233S(R) & GAGTAGCAcCTTCCAcGaCCAGGAGAGGCACTGGG & 35 & 3 & 79.4 \\
\hline hGHBP-S237C(F) & GATGtGCTAAGAATTCGAGCTCCGTCGACAA & 31 & 1 & 76.3 \\
\hline hGHBP-S237C(R) & TTAGCaCATCTGAGGAAGTGTTACATAGAGCACC & 34 & 1 & 76.8 \\
\hline pGHBP-S237C(F) & GATGtGCTAAGAATTCGAGCTCCGTCGACAA & 31 & 1 & 76.3 \\
\hline pGHBP-S237C(R) & TTAGCaCATCTGAGGAAGTGTTACATAGAGCACC & 34 & 1 & 76.8 \\
\hline hGHR1-255R235C(F) & AACAAtgcAACTCTGGAAATTATGGC & 26 & 3 & 59.8 \\
\hline hGHR1-255R235C(R) & TIgcaTTGTTGGATCTCACA & 21 & 3 & 58.7 \\
\hline hGHR1-638R235C(F) & AACAAtgcAACTCTGGAAATTATGGC & 26 & 3 & 59.8 \\
\hline hGHR1-638R235C(R) & TgcaTTGTTGGATCTCACA & 21 & 3 & 58.7 \\
\hline
\end{tabular}

$T_{\mathrm{m}}$ is the melting temperature of mutagenic oligonucleotide primers annealing with the WT template to $50 \%$. For all primers, the mutagenesis oligonucleotides are denoted in lowercase. 
away from the $5^{\prime}$-terminus. Thus, both forward and reverse primers shared the mutagenic region, but held a 917 base-long overlapping sequence. The total length of the primers varied from 21 to $38 \mathrm{nt}$. The melting temperature $\left(T_{\mathrm{m}}\right)$ was calculated using the formula provided by the manufacturer Agilent Technologies: $T_{\mathrm{m}}=81.5+0.41(\%$ GC)-675/N - \% mismatch. Here, $N$ is the primer length in bases. All the primers were synthesized by Generay Biotechnology (Shanghai, China). Mutagenic reaction was performed in $50 \mathrm{ul}$ of PCR mix containing $2 \mathrm{ng}$ of pET20b (+)-hGH (WT) as template, $200 \mathrm{nM}$ primer and $2.5 \mathrm{U} \mathrm{Pfu}$ DNA polymerase (Fermentas, Canada). The PCR temperature profile was: an initial denaturation at $94^{\circ} \mathrm{C}$ for $3 \mathrm{~min}$, followed by 30 cycles with each at $94^{\circ} \mathrm{C}$ for $30 \mathrm{sec}$, $55^{\circ} \mathrm{C}$ for $30 \mathrm{sec}$ and $72^{\circ} \mathrm{C}$ for $0.5 \mathrm{~kb} / \mathrm{min}$, and a final extension at $72^{\circ} \mathrm{C}$ for $5 \mathrm{~min}$. The PCR products of SDM were transformed into E. coli DH5alpha competent cells.

\section{Mutant screening by gradient PCR}

For a more efficient mutant screening, a $T_{\mathrm{C}}$-PCR with the SDM-generated mutants as templates and the same mutagenic primer pairs was designed to replace the traditional $D p n$ I digestion. The $T_{\mathrm{c}}$, which can select against mismatched parental and undesired mutant templates from completely matched desired mutants was identified by a set of gradient-PCR with the generated clones from SDM and the same primer pairs listed in Table 1. Five clones were randomly collected from the transformants of each mutant and underwent PCR with the WT template as criteria. Six different annealing temperatures were designed according to the $T_{\mathrm{m}}$ of the primers bound to the WT template. Among these 6 tested temperatures, the annealing temperature at which there was still substantial amplification of the mutant template but no detectable products of the WT template was identified as the $T_{\mathrm{c}}$. The PCR was performed in a final volume of $20 \mu \mathrm{l}$ PCR mix containing $20 \mathrm{ng}$ template, $200 \mathrm{nM}$ of each primer, $2 \mu \mathrm{l} 10 \times$ reaction buffer $(37.5 \mathrm{mM}$ Tris- $\mathrm{HCl}$, $10 \mathrm{mM}\left(\mathrm{NH}_{4}\right)_{2} \mathrm{SO}_{4}, 2 \mathrm{mM} \mathrm{Mg}{ }^{2+}, 0.01 \%$ Tween20) and $2 \mathrm{U}$ Taq DNA polymerase. The temperature profile was: initial denaturation at $94^{\circ} \mathrm{C}$ for 3 min followed by 35 cycles with each at $94^{\circ} \mathrm{C}$ for $30 \mathrm{sec}$, annealing at the desired temperature for $30 \mathrm{sec}$, extension for $2 \mathrm{~kb} / \mathrm{min}$ and a final extension at $72^{\circ} \mathrm{C}$ for $5 \mathrm{~min}$. The PCR products were then electrophoresed in $0.8 \%$ agarose gel to check their abundance. The clones that maintained detectable PCR products up to $T_{\mathrm{c}}$ or over were assumed as desired mutants and those that lost detectable products, the parental molecules. The results were then confirmed by DNA sequencing. Data of sequences were analyzed by the software Genetool lite version 1.0.

To evaluate the accuracy of the gradient-PCR identified $T_{\mathrm{c}}$ in distinguishing WT from mutant, a series of $T_{\mathrm{c}^{-}}$ PCR screening were performed with different target
genes(hGH-D112K, hGH-D112G, hGH2V3-P233S, hGHR-R255C, hGHBP-S237C and pGHBP-S237C) after $\mathrm{SDM}$, and the results were confirmed by sequence analysis.

\section{Colony gradient PCR}

Colony PCR method is more widely used than plasmid PCR method in confirming the gene insertion into a vector. To test the feasibility of the $T_{c}$-PCR used as a colony $\mathrm{PCR}$, a portion of bacterial colonies containing the desired plasmid were picked using a sterile toothpick. The tip of the toothpick was placed in $180 \mathrm{ul}$ of the PCR mixture and gently shaken. The PCR mix was then aliquoted into $25 \mathrm{ul}$ aliquots. PCR was carried out using the gradient PCR protocol described above except that the initial denaturation time increased to 7 minutes.

\section{Data analysis}

Data were statistically analyzed with SPSS version 18.0 (SPSS Inc., IL). A correlation analysis was performed to assess whether and how strongly the gradient PCRidentified $T_{\mathrm{c}}$ is related to $T_{\mathrm{m}}$ and other features of the primers (including the length, mismatch, \%GC and the number of bases from $3^{\prime}$ - or $5^{\prime}$-terminus to the mutation site). A stepwise linear regression was used to model the relationship between $T_{\mathrm{c}}$ and $T_{\mathrm{m}}$.

\section{Results}

Critical annealing temperature identified by gradient-PCR

Figure $1 \mathrm{~A}$ showed the results of mutant screening by gradient PCR using D112K forward and reverse primers which contained two designed mutations. At the gradient annealing temperatures from $64 \sim 69^{\circ} \mathrm{C}$, the WT template, as well as two clones (D112K-1 and D112K-3) out of five randomly collected from the transformants without $D p n$ I digestion, showed detectable products only at annealing temperatures of 64 and $65^{\circ} \mathrm{C}$, whereas the other three clones (D112K-2, D112K-4 and D112K-5) maintained detectable up to $67^{\circ} \mathrm{C}$ or higher. Thus the $T_{\mathrm{c}}$ of $\mathrm{D} 112 \mathrm{~K}$ was identified as $66^{\circ} \mathrm{C}$. Sequence analysis (Figure 1B) demonstrated that the two clones, D112K-1 and D112K-3, which lost detectable products at $T_{\mathrm{c}}\left(66^{\circ} \mathrm{C}\right)$ were WT molecules and the other three were the desired mutants (GAC was changed into AAA).

Figure $1 C$ showed the gradient PCR screening for a single-site-mutant, D112G. The WT template and three clones (D112G-1, D112G-3 and D112G-5) lost detectable products at $68^{\circ} \mathrm{C}$, whereas the other two (D112G-2 and 4) maintained detectable over $68^{\circ} \mathrm{C}$; this annealing temperature was therefore identified as the $T_{\mathrm{c}}$ of D112G. Similarly, DNA sequence analysis demonstrated that the three clones becoming undetectable at the $T_{\mathrm{c}}$ were WT molecules and the other two (D112G-2 and 4) still detectable at or over $T_{\mathrm{c}}$ were desired mutants. 

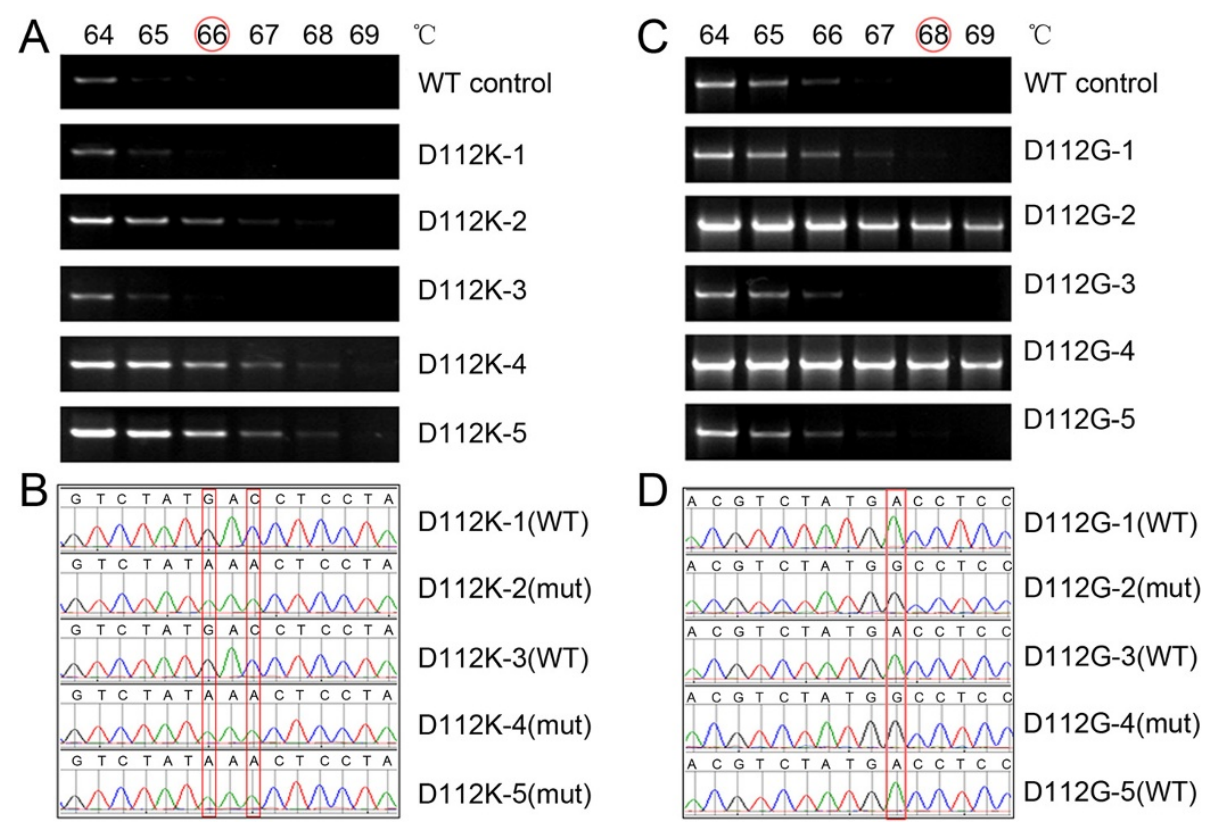

Figure 1 Gradient PCR screening and sequence analysis of the transformants generated by SDM without Dpn I digestion. A. Gradient PCR screening of multiple-site-mutant D112K. Five transformants were examined with the WT template as criteria under a set of gradient annealing temperatures from $64^{\circ} \mathrm{C}$ to $69^{\circ} \mathrm{C}$. The identified $T_{c}$ was $66^{\circ} \mathrm{C}$ at which the WT template lost detectable products. B. Sequence analysis of the same transformants, which shows that three transformants (D112K-2, 4 and 5) still detectable at annealing temperatures over $T_{c}$ were desired mutants. C. Gradient PCR screening of single-site-mutant D112G. The identified $T_{c}$ was $68^{\circ} \mathrm{C}$. D. Sequence analysis of the same transformants showing that two transformants (D112G-2 and 4) still detectable at annealing temperatures over $T_{c}$ were desired mutants.

The gradient-PCR identified $T_{\mathrm{c}}$ for all tested primers were listed in Table 2.

\section{Mutant selection against WT and undesired mutants by critical annealing temperature PCR}

Figure 2 showed the results of PCR screening with the gradient-PCR-identified $T_{\mathrm{c}}$ as annealing temperature and sequence analysis on 16 transformants of $\mathrm{D} 112 \mathrm{~K}$ and D112G after SDM without Dpn I digestion. At annealing temperature of $T_{\mathrm{C}}\left(66^{\circ} \mathrm{C}\right.$ for $\mathrm{D} 112 \mathrm{~K}$ and $68^{\circ} \mathrm{C}$ for $\left.\mathrm{D} 112 \mathrm{G}\right)$, the clones that showed substantial PCR products were all desired mutants as demonstrated by DNA sequencing; whereas those that lost detectable products were either WT or undesired mutants that had "mistake" located in mutagenic sequence segments.

$T_{\mathrm{c}}$-PCR screening and sequence analysis on all tested clones of D112K and D112G were shown in Table 3.

\section{Reliability of critical annealing temperature PCR at different initial concentrations of template}

To test the reliability of $T_{\mathrm{c}}$-PCR at different initial concentrations of template, both WT and mutant plasmids (10$80 \mathrm{ng}$ in 50 ul reaction volume) of D112K and D112G were used for PCR with $T_{\mathrm{c}}$ as annealing temperature. As shown in Figure 3, in the WT templates no detectable products could be observed at all tested concentrations, but in the mutant templates the PCR bands were detec- table at $10 \mathrm{ng}$, and enhanced with concentrations from 10 to 50 or $60 \mathrm{ng}$.

Relationship between gradient PCR-identified $T_{\mathrm{c}}$ and $T_{\mathrm{m}}$ The correlation analysis on relationship of gradient PCRidentified $T_{\mathrm{c}}$ to $T_{\mathrm{m}}$ and other features of the primers (Table 2) showed that the PCR-identified $T_{\mathrm{c}}$ of 9 tested primer pairs of hGH mutants were correlated with their $T_{\mathrm{m}}(\mathrm{r}=0.804, \mathrm{P}<0.0001)$. The relationship between $T_{\mathrm{c}}$ and $T_{\mathrm{m}}$ were statistically modeled with the stepwise linear regression. Taking $T_{\mathrm{m}}$ as the explanatory variable, the linear regression model for $T_{\mathrm{c}}$ and $T_{\mathrm{m}}$ was expressed as the following regression equation:

$T_{\mathrm{c}}=48.81+0.253^{*} T_{\mathrm{m}}$, here, $T_{\mathrm{m}}$ is the melting temperature of mutagenic primer pairs with WT template.

To test the repeatability of the regression equationderived $T_{\mathrm{c}}$, a series of gradient PCR were run with different target genes (hGH-D112K, hGH-D112G, hGH2V3-P233S, hGHR-R255C, hGHBP-S237C and pGHBP-S237C). As a representative, hGH2V3-P233S contained 3 designed mutations. According to the regression equation above, the predicted $T_{\mathrm{c}}$ should be: $T_{\mathrm{cF}}$ (forward primer) $=69.21^{\circ} \mathrm{C}$ and $T_{\mathrm{cR}}$ (reverse primer) $=68.91^{\circ} \mathrm{C}$. Thus, a set of annealing temperatures were selected from 68 to $72^{\circ} \mathrm{C}$. As shown in Figure 4 The WT template (pcDNA3.1hGH2V3) lost detectable products at $70^{\circ} \mathrm{C}$, whereas the mutant template (pcDNA3.1-GH2V3-P233S) maintained 
Table 2 Features of the primers and their gradient-PCR identified- $T_{c}$

\begin{tabular}{|c|c|c|c|c|c|c|c|}
\hline Primer & Length & Mismatches & $\% G C$ & $\mathrm{Nt3}^{*}$ & $\mathrm{Nt} 5^{\Delta}$ & $T_{\mathrm{m}}$ & $T_{c}$ \\
\hline $\mathrm{D} 112 \mathrm{G}(\mathrm{F})$ & 29 & 1 & 51.7 & 23 & 5 & 76.0 & 68 \\
\hline $\mathrm{D} 112 \mathrm{G}(\mathrm{R})$ & 26 & 1 & 57.7 & 20 & 5 & 75.3 & 68 \\
\hline $\mathrm{D} 112 \mathrm{~K}(\mathrm{~F})$ & 29 & 2 & 41.4 & 22 & 4 & 68.3 & 66 \\
\hline $\mathrm{D} 112 \mathrm{~K}(\mathrm{R})$ & 26 & 2 & 46.2 & 19 & 4 & 66.8 & 66 \\
\hline $14 V(F)$ & 27 & 1 & 48.1 & 21 & 5 & 72.5 & 67 \\
\hline $14 V(R)$ & 32 & 1 & 40.6 & 28 & 3 & 73.9 & 67 \\
\hline L45D(F) & 36 & 3 & 52.8 & 28 & 5 & 76.1 & 67 \\
\hline L45D(R) & 37 & 3 & 40.5 & 27 & 7 & 71.8 & 67 \\
\hline $\mathrm{E} 56 \mathrm{D}(\mathrm{F})$ & 27 & 1 & 51.9 & 21 & 5 & 74.1 & 67 \\
\hline E56D(R) & 31 & 1 & 48.4 & 23 & 7 & 76.3 & 67 \\
\hline R64D(F) & 25 & 3 & 52.0 & 15 & 7 & 63.8 & 65 \\
\hline $\mathrm{R} 64 \mathrm{D}(\mathrm{R})$ & 27 & 3 & 59.3 & 20 & 4 & 69.7 & 65 \\
\hline N109Y(F) & 38 & 2 & 47.4 & 31 & 4 & 77.9 & 69 \\
\hline N109Y(R) & 30 & 2 & 60.0 & 24 & 3 & 76.9 & 69 \\
\hline $\mathrm{D} 116 \mathrm{~F}(\mathrm{~F})$ & 33 & 2 & 45.5 & 27 & 4 & 73.6 & 69 \\
\hline $\mathrm{D} 116 \mathrm{~F}(\mathrm{R})$ & 38 & 2 & 52.0 & 29 & 7 & 77.9 & 69 \\
\hline $\mathrm{R} 64 \mathrm{M}(\mathrm{F})$ & 24 & 1 & 47.4 & 16 & 7 & 68.0 & 67 \\
\hline $\mathrm{R} 64 \mathrm{M}(\mathrm{R})$ & 25 & 1 & 40.5 & 21 & 3 & 71.8 & 67 \\
\hline hGH2V3-P233S(F) & 36 & 3 & 63.9 & 19 & 3 & 80.6 & 70 \\
\hline hGH2V3-P233S(R) & 35 & 3 & 62.9 & 17 & 4 & 79.4 & 70 \\
\hline hGHBP-S237C(F) & 31 & 1 & 48.4 & 26 & 4 & 76.3 & 69 \\
\hline hGHBP-S237C(R) & 34 & 1 & 44.1 & 28 & 5 & 76.8 & 69 \\
\hline pGHBP-S237C(F) & 31 & 1 & 48.4 & 26 & 4 & 76.3 & 69 \\
\hline pGHBP-S237C(R) & 34 & 1 & 44.1 & 28 & 5 & 76.8 & 69 \\
\hline hGHR1-255R235C(F) & 26 & 3 & 38.5 & 18 & 5 & 59.8 & 60 \\
\hline hGHR1-255R235C(R) & 21 & 3 & 38.1 & 16 & 2 & 58.7 & 60 \\
\hline hGHR1-255R235C(F) & 26 & 3 & 38.5 & 18 & 5 & 59.8 & 60 \\
\hline hGHR1-255R235C(R) & 21 & 3 & 38.1 & 16 & 2 & 58.7 & 60 \\
\hline
\end{tabular}

* The number of bases from $3^{\prime}$ - terminus to the mutation site. $\Delta$ The number of bases from $5^{\prime}$-terminus to the mutation site.

\section{D112K}

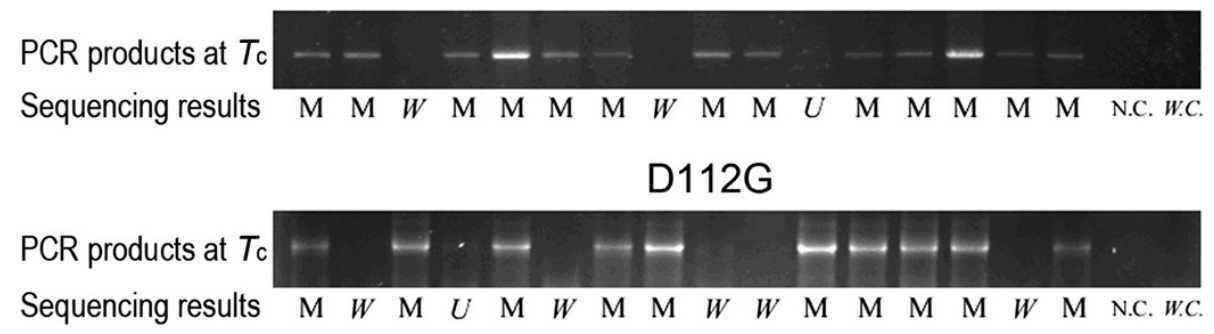

Figure $2 T_{\mathrm{c}}-\mathrm{PCR}$ screening and sequence analysis on 16 clones of D112K and D112G after SDM. The $T_{\mathrm{c}}$ is $66^{\circ} \mathrm{C}$ for $\mathrm{D} 112 \mathrm{~K}$ and $68^{\circ} \mathrm{C}$ D112G. The sequencing results are represented by $\mathrm{M}$ (desired mutant), W (wild type) and U (undesired mutant), respectively. N.C and W.C represent negative and WT controls, respectively. 
Table $3 T_{\mathrm{c}}$-PCR screening and sequence analysis on clones of D112K and D112G

\begin{tabular}{|c|c|c|c|c|c|c|c|c|c|c|}
\hline \multirow[t]{3}{*}{ Primers } & \multirow{3}{*}{$\begin{array}{l}T_{\mathrm{c}} \\
\left({ }^{\circ} \mathrm{C}\right)\end{array}$} & \multirow{3}{*}{$\begin{array}{l}\text { Tested } \\
\text { clones }\end{array}$} & \multicolumn{8}{|c|}{$T_{\mathrm{c}} \mathrm{PCR}$ and sequence analysis } \\
\hline & & & \multirow{2}{*}{$\begin{array}{c}T_{\mathrm{c}}-\mathrm{PCR} \\
\text { detect- } \\
\text { able }\end{array}$} & \multicolumn{3}{|c|}{ Sequencing } & \multirow{2}{*}{$\begin{array}{c}T_{\mathrm{c}}-\mathrm{PCR} \\
\text { undetect- } \\
\text { able }\end{array}$} & \multicolumn{3}{|c|}{ Sequencing } \\
\hline & & & & Desired mut. & WT & Undesired mut. & & Desired mut. & WT & Undesired mut. \\
\hline D112K & 66 & 49 & 38 & 38 & 0 & 0 & 11 & 0 & 10 & 1 \\
\hline D112G & 68 & 50 & 26 & 26 & 0 & 0 & 24 & 0 & 23 & 1 \\
\hline
\end{tabular}

substantial products at $70^{\circ} \mathrm{C}$. The PCR-identified $T_{\mathrm{c}}\left(70^{\circ} \mathrm{C}\right)$ was very close to the equation predicted $\left(T_{\mathrm{cF}}=69.21^{\circ} \mathrm{C}\right.$ and $\left.T_{\mathrm{cR}}=68.91^{\circ} \mathrm{C}\right)$. Similarly, in the tests using other different genes with different length, the PCR-identified $T_{\mathrm{c}}$ were also very close to the equation predicted $T_{\mathrm{c}}$ (shown in Figure 4).

\section{Critical annealing temperature PCR screening with bacterial colonies as templates or with different sources of Taq DNA Polymerase}

When using the bacterial colonies containing the desired plasmid (PET20b(+)/hGH-D112K and -D112G) as templates, a $T_{c}$ could be identified by a gradient PCR and the PCR-identified $T_{\mathrm{C}}\left(66^{\circ} \mathrm{C}\right.$ and $\left.68^{\circ} \mathrm{C}\right)$ were also very close to the equation predicted (D112K: $T_{\mathrm{cF}}=66.09^{\circ} \mathrm{C}$ and $T_{\mathrm{cR}}=65.72^{\circ} \mathrm{C} ; \quad \mathrm{D} 112 \mathrm{G} ; \quad T_{\mathrm{cF}}=68.04^{\circ} \mathrm{C}$ and $T_{\mathrm{cR}}=$ $67.86^{\circ} \mathrm{C}$ ) (Figure 5 and Table 2). However, the present experiment suggests that the initial denaturation time should be increased to $7 \mathrm{~min}$ to enhance denaturation of the plasmids in E. coli DH5alpha cells.

A similar result was also obtained when we repeated the study with the enzymes from different batches or different companies, such as recombinant Taq DNA Polymerase (Fermentas, Canada), Taq DNA Polymerase (Takara, Japan), and $2 \times$ Taq master mix (Dsbio, Peking).

\section{Discussion}

Distinguishing desired mutants from parental template and undesired mutations in SDM is still a problem not well solved. Although as a favorite method, digestion of Dpn I can eliminate fully methylated WT DNA (parental strands from bacterial strains), around $20-30 \%$ of hemimethylated WT molecules (parental strand combined with PCR-generated strand) could not be removed $[6,8]$ due to hemi-methylated DNA in the PCR products is more resistant to $D p n$ I $[3,12]$. In addition, $D p n$ I cannot select against undesired mutations.

Liu and Naismith [6] recently presented a strategy to minimize the parental molecules by enhancing the PCR efficiency. In their design scheme, each pair of primers contained non-complementary sequences at their $3^{\prime}$ terminus and primer-primer complementary sequences at the $5^{\prime}$ terminus. The mutation sites were placed in the complementary region. The nonoverlapping sequences were longer than the complementary sequences so that they have a $T_{\mathrm{m}}$ higher than that of primer-primer complementary sequences. Thus the primer dimerization was eliminated and the new synthesized PCR products could be used as the templates in the subsequent PCR cycles. This design can significantly increase the PCR efficiency and requires less template DNA.

On the basis of Liu and Naismith, we designed a modified protocol in which the Dpn I digestion was replaced by a $T_{\mathrm{c}}$-PCR that could select against parental molecules and undesired mutations in mutagenic sequence segments at an accuracy of $100 \%$. In this PCR the primers were the same used to introduce the mutations and the templates were SDM-generated clones. Thus theoretically the primers completely match the desired mutant and should have an annealing temperature to the mutant higher than to any other mismatched templates such as parental molecules and undesired mutants. Since DNA chemosynthesis is much more errorprone than DNA replication by polymerase [13-16], it is important to eliminate the undesired mutants generated by mistake primers. The key for this PCR screening is a

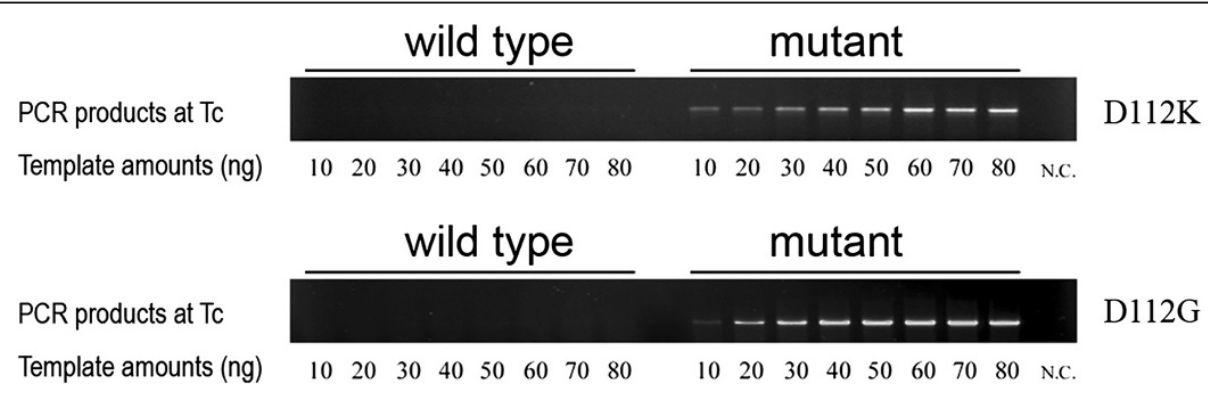

Figure $3 T_{\mathrm{c}}-\mathrm{PCR}$ with different amounts of hGH WT, and mutants $\mathrm{D} 112 \mathrm{~K}$ and D112G as templates. 


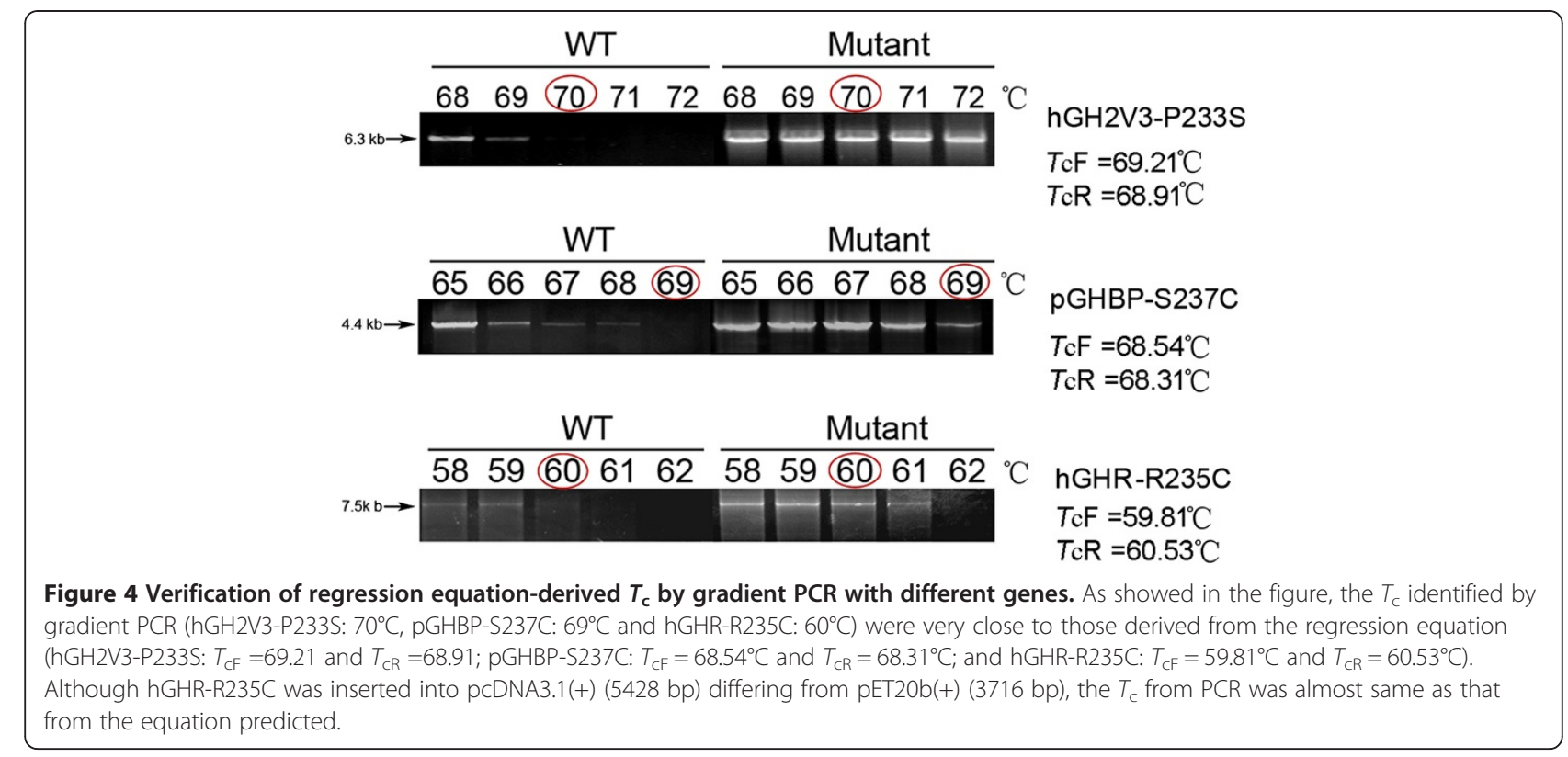

critical annealing temperature $\left(T_{\mathrm{c}}\right)$ that can discriminate mismatched templates from the matched desired mutant. Using a gradient PCR, we identified the $T_{\mathrm{c}}$ for each mutant template and demonstrated that it was correlated to the primer's $T_{\mathrm{m}}$. Thus, in practical applications, the $T_{\mathrm{c}}$ can be easily calculated with a regression equation, $T_{\mathrm{c}}=48.81+0.253 * T_{\mathrm{m}}$.

The reliability of the $T_{\mathrm{c}}$-PCR screening was confirmed by using different vectors harboring different genes (ranging from $573 \mathrm{bp}$ to $1920 \mathrm{bp}$ ) and by employing Taq

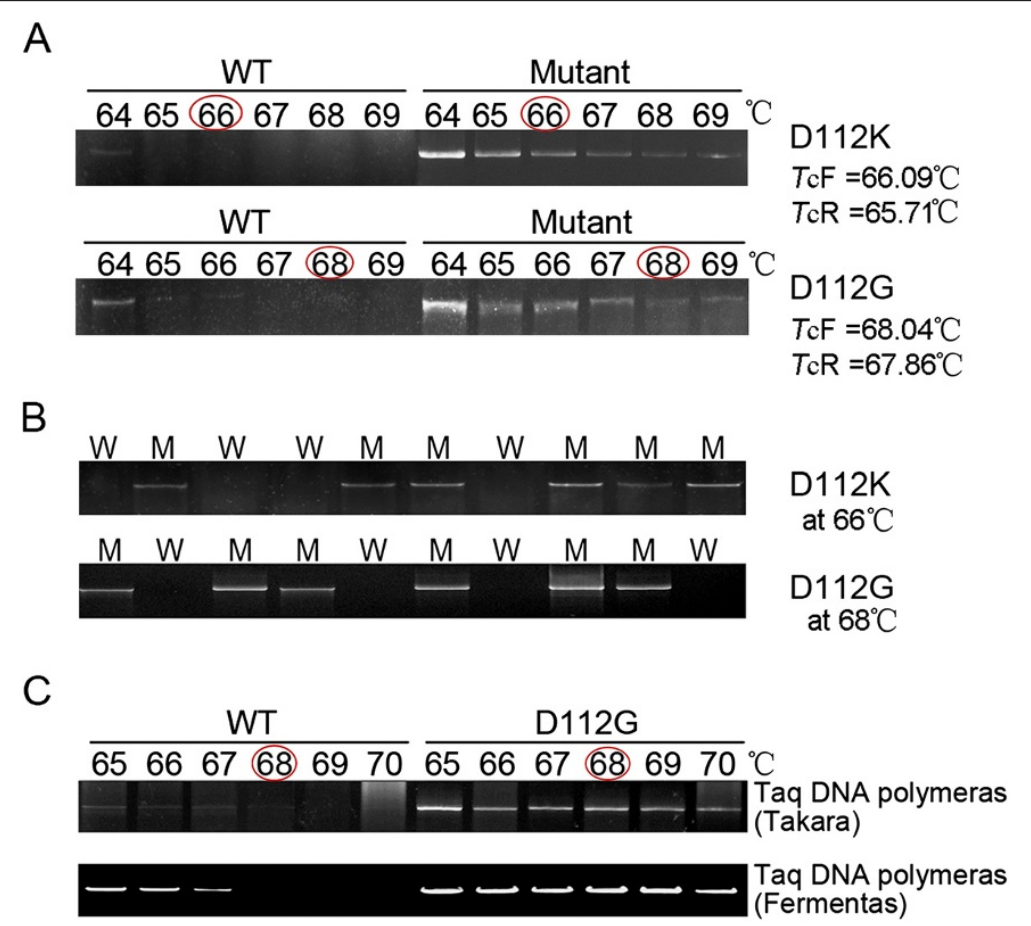

Figure $5 T_{\mathrm{c}}$-PCR screening with bacterial colonies as templates or with Taq DNA polymerase from different sources. A. Colony gradient PCR performed at indicated annealing temperatures using bacterial colonies carrying hGH WT or hGH mutant (D112K or D112G) plasmid to detect their $T_{c}$. B. Twenty colonies screened at $T_{c}$ after SDM. The sequencing results are represented by $M$ (desired mutant) and $W$ (wild type), respectively. C. Gradient PCR at the indicated annealing temperatures with Taq DNA Polymerases from different companies, such as Fermentas and Takara. 
polymerases from different sources. Furthermore, the feasibility of the $T_{\mathrm{c}}$-PCR as a colony PCR was tested with bacterial colonies containing the desired plasmid. These suggest that the $T_{\mathrm{c}}$-PCR can have a wider usage.

\section{Conclusions}

In summary, the new protocol presented in the present study introduced a $T_{\mathrm{c}}$-PCR screening to replace the $D p n \mathrm{I}$ digestion, which can more efficiently and accurately select against parental molecules and undesired mutants which have a "mistake" in mutagenic sequence segments.

\section{Abbreviations}

WT: Wild type; SDM: Site-directed mutagenesis system; $T_{c}-P C R$ : Critical annealing temperature-PCR.

\section{Competing interests}

The authors have declared that no competing interests exist.

\section{Authors' contributions}

$Y L$ designed the study, carried out all experiments, acquired and analyzed the data, drafted and revised the manuscript; T W analyzed the data and performed the statistical analysis; $X C$ and $Y Z$ carried out the site-directed mutagenesis and gradient PCR; J S participated in the design of the study and revised the manuscript; $Y W$ designed the study, analyzed the data, wrote and revised the manuscript, supervised and supported the study. All authors read and approved the final manuscript.

\section{Acknowledgements}

This study was funded by The National Natural Science Foundation of China (30870924, Wan Yu).

\section{Author details}

'Department of Physiology, School of Basic Medical Sciences, Wuhan University, Hubei 430071, People's Republic of China. ${ }^{2}$ Center for Medical Research, Wuhan University, Hubei 430071, People's Republic of China. ${ }^{3}$ Department of Anatomical Sciences, School of Basic Medical Sciences, Wuhan University, Hubei 430071, People's Republic of China. ${ }^{4}$ Department of Gastroenterology, Zhongnan Hospital, Wuhan University, Hubei 430071, People's Republic of China.

Received: 23 August 2012 Accepted: 19 February 2013

Published: 11 March 2013

\section{References}

1. Wan Y, McDevitt A, Shen B, Smythe ML, Waters MJ: Increased site 1 affinity improves biopotency of porcine growth hormone. Evidence against diffusion dependent receptor dimerization. J Biol Chem 2004, 279(43):44775-44784.

2. Wang H, Zhou N, Ding F, Li Z, Chen R, Han A, Liu R: An efficient approach for site-directed mutagenesis using central overlapping primers. Anal Biochem 2011, 418(2):304-306.

3. Ling MM, Robinson BH: Approaches to DNA mutagenesis: an overview. Anal Biochem 1997, 254(2):157-178.

4. Braman J, Papworth C, Greener A: Site-directed mutagenesis using doublestranded plasmid DNA templates. Methods Mol Biol 1996, 57:31-44.

5. Nelson RM, Long GL: Binding of protein S to C4b-binding protein. Mutagenesis of protein S. J Biol Chem 1992, 267(12):8140-8145.

6. Liu H, Naismith JH: An efficient one-step site-directed deletion, insertion, single and multiple-site plasmid mutagenesis protocol. BMC Biotechnol 2008, 8:91

7. Sarkar G, Sommer SS: The "megaprimer" method of site-directed mutagenesis. Biotechniques 1990, 8(4):404-407.

8. Edelheit O, Hanukoglu A, Hanukoglu I: Simple and efficient site-directed mutagenesis using two single-primer reactions in parallel to generate mutants for protein structure-function studies. BMC Biotechnol 2009, 9:61.
9. Vandeyar MA, Weiner MP, Hutton CJ, Batt CA: A simple and rapid method for the selection of oligodeoxynucleotide-directed mutants. Gene 1988, 65(1):129-133.

10. Ishii TM, Zerr P, Xia XM, Bond CT, Maylie J, Adelman JP: Site-directed mutagenesis. Methods Enzymol 1998, 293:53-71.

11. Li J, Li C, Xiao W, Yuan D, Wan G, Ma L: Site-directed mutagenesis by combination of homologous recombination and Dpn I digestion of the plasmid template in Escherichia coli. Anal Biochem 2008, 373(2):389-391.

12. Li F, Liu SL, Mullins Jl: Site-directed mutagenesis using uracil-containing double-stranded DNA templates and Dpn I digestion. Biotechniques 1999, 27(4):734-738

13. Cline J, Braman JC, Hogrefe HH: PCR fidelity of pfu DNA polymerase and other thermostable DNA polymerases. Nucleic Acids Res 1996, 24(18):3546-3551.

14. Hecker KH, Rill RL: Error analysis of chemically synthesized polynucleotides. Biotechniques 1998, 24(2):256-260.

15. Hoover DM, Lubkowski J: DNAWorks: an automated method for designing oligonucleotides for PCR-based gene synthesis. Nucleic Acids Res 2002, 30(10):e43.

16. Xiong AS, Peng RH, Zhuang J, Gao F, Li Y, Cheng ZM, Yao QH: Chemical gene synthesis: strategies, softwares, error corrections, and applications. FEMS Microbiol Rev 2008, 32(3):522-540.

doi:10.1186/1472-6750-13-21

Cite this article as: Liu et al:: A mutant screening method by critical annealing temperature-PCR for site-directed mutagenesis. BMC Biotechnology 2013 13:21.

\section{Submit your next manuscript to BioMed Central and take full advantage of:}

- Convenient online submission

- Thorough peer review

- No space constraints or color figure charges

- Immediate publication on acceptance

- Inclusion in PubMed, CAS, Scopus and Google Scholar

- Research which is freely available for redistribution 